\title{
The Mosaics of the Castellitto Villa in Ramacca (Catania - Sicily): Review of Published Data and New Perspectives
}

\section{Ramacca'daki (Katanya - Sicilya) Castellitto Villası'nın Mozaikleri: Yayınlanan Verilerin Gözden Geçirilmesi ve Yeni Perspektifler}

\author{
Dominique Maria DI CARO*
}

(Received 30 November 2019, accepted after revision 15 August 2020)

\begin{abstract}
During the last seasons (May-July 2019), the archaeological excavations of the Castellitto villa in the territory of Ramacca, in Catania province, which were carried out by Soprintendenza Archeologica di Catania, under the direction of doctor Maria Teresa Magro, brought a new source of knowledge which reviews and highlights new aspects from the published data.

This paper focuses on new information that allow us to reconstruct the history and the structure of the rural villa with attention to the study of mosaics. The study of mosaic flooring has covered both the unpublished mosaics recently discovered and the revision of published data during the 80's. According to the current state of research, polychrome geometric mosaics have come to light, which consist of large shaped patterns and can be dated between $4^{\text {th }}-5^{\text {th }}$ century AD. Finally, future scheduled excavations will be able to clarify the function and chronology of this late roman residential complex.
\end{abstract}

Keywords: Sicily, Castellitto, statio Capitoniana, rustic villa, Late Antique mosaics.

Öz

2019 yll Mayls ve Temmuz aylarl boyunca, Katanya Eyaleti'nin Ramacca Bölgesi'nde Katanya Kültürel Mirası Koruma Dairesi tarafindan Doktor Maria Teresa Magro başkanlığında Castellitto Villası'nda yapılan arkeolojik kazılar, yayınlanan verilerden, yeni yönleri inceleyen ve vurgulayan bir bilgi kaynağını ortaya çıkardl.

Bu makale, mozaik çalışmasına odaklanarak kırsaldaki villanın tarihini ve yapısını yeniden yapılandırmamıza izin veren yeni bilgilere odaklanmaktadır. Mozaik döşeme çalışmaları, hem yakın zamanda keşfedilip yayımlanmamış hem de 80'lerde yayınlanan verilerin revizyonunu kapsamaktadır. Araştırmanın mevcut durumuna göre, büyük şekilli desenlerden oluşan ve IS 4. - 5. yüzyıl arasında tarihlenebilen çok renkli geometrik mozaikler ortaya çıkmıştır. Son olarak, gelecekteki planlı kazılar, bu Geç Roma konut kompleksinin işlevini ve kronolojisini netleştirebilecektir.

Anahtar Kelimeler: Sicilya, Castellitto, statio Capitoniana, kırsal villa, Geç Antik Dönem mozaikleri.

\footnotetext{
"Dominique Maria DI CARO, Universidad Carlos III de Madrid (in international cotutela with the University of Calabria - UNICAL), Dpto. de Humanidades: Historia, Geografía y Arte. c/ Madrid, 126, 28903 Getafe, Madrid, Spain. (D https://orcid.org/0000-0001-6030-9841. E-mail: arkeodomi89@gmail.com

This discussion of a work in progress aims to offer a review of published data and its preliminary presentation given by the recent excavation campaign related to the mosaics of the Castellitto villa, researched in the doctoral thesis currently in progress of the writer, entitled "Mosaicos tardoantiguos del sur de Italia: itinerario topográfico-iconográfico". Many thanks to Maria Teresa Magro (officer archeologist of the Soprintendenza Archeologica di Catania), operating director of the excavation, for giving me the permission to directly see the dig site and study also the mosaics recently discovered (which will be dealt with separately), for her availability and provided support. I also thank Marco Michele Mosca for the correction of the English translation of the text.

Concessions were made by Assessorato Regionale per i Beni Culturali e l'Identità Siciliana - Soprintendenza per i Beni Culturali di Catania. Further reproduction or duplication activities by any means are expressly and strictly prohibited.
} 
The Roman villa of Castellito (Monte Turcisi IGM f. 269, II, NO; Fig. 1), in the territory of Ramacca, is $2.5 \mathrm{~km}$ southeast of the Masseria Castellito and about 2 $\mathrm{km}$ west of the river Dittaino, on a plateau about $106 \mathrm{~m}$ above sea level, looking to the North-Eastern side of Etna.

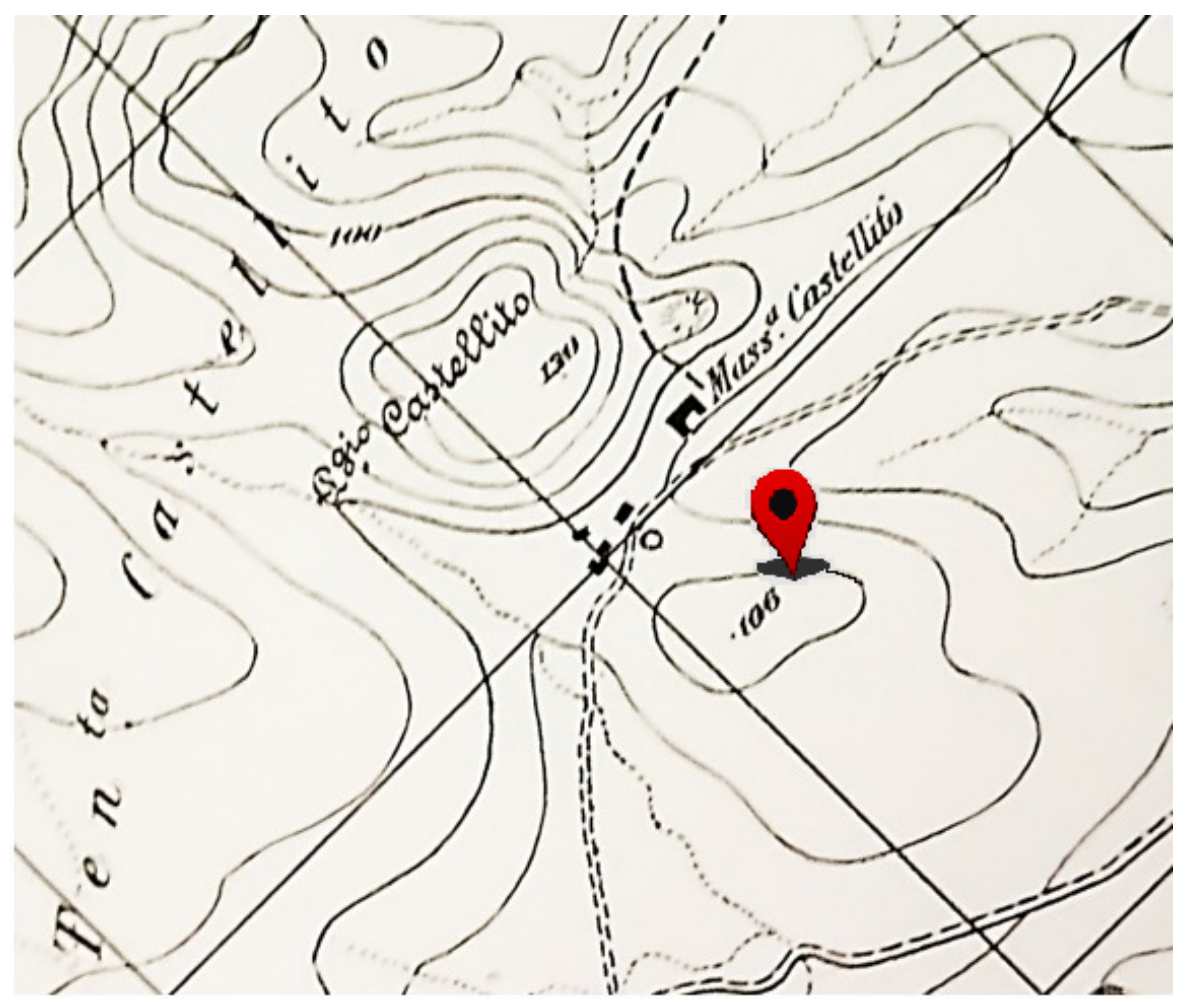

Since the Early Bronze Age, the area has been intensely frequented as attested by many identified settlements of facies castellucciana (Procelli 1976-1977: 615-618). The same occurred during the Roman imperial period with the high concentration of sites that characterize the territory between Castel di Iudica and Ramacca, such as the districts Franchetto (in front of Castellito), Torricella, Margherito, Gallinella, Ventrelli (Spigo 1982-1983: 341-344; Bonacini - Turco 2015: 1-12).

From this last district comes the well-known sepulchral epigraph of Abdalas, magister ovium of Domizia Longina, wife of the emperor Domiziano, who had inherited from his father a large latifundium between Ramacca and Aidone (Salmeri 1984: 21), attesting the presence of imperial property in this area.

The Castellitto villa is currently reachable from Catania along the SS 192, which becomes SS 288 (Regia trazzera 477) towards Aidone direction. At the junction Jannarello one should drive for about $4 \mathrm{~km}$ until the exit for the SB21, on the right, and then going ahead for few kilometres in that direction. The site, based on the Itinerarium Antonini, lies along the route of the Roman road Catina-Agrigentum and was identified by the discoverers with the first statio, Capitoniana (Albanese - Procelli 1988-1989: 7-22).

In this regard, prudently, Bonacini states that "... it is not improbable that the villa of Castellito [...] is part of the praediis Capitonianibus [...]. However, it turns out to be too close to Catania, compared to distances passed down to us: we should think of a mistake in the manuscript tradition, but the distance of about $28 \mathrm{~km}$ would correspond to the XIX m. p. latin. It is unthinkable that XIX was misspelled as XXIV for an error in transcription" (Bonacini 2010: 80). There are different proposals about the localization of the statio in the territory of Ramacca:
Figure 1

Extract of I.G.M. topographic map f. 269, II, N/O (re-elab. by D. Di Caro). 
Figure 2

Rooms of the northern pavilion with mosaics (from the video in https://www.facebook. com/regionesiciliana/videos/522132625229 $592 / ? \mathrm{v}=522132625229592 \&$ external_log_id $=48 \mathrm{db} 2 \mathrm{e} 8 \mathrm{~d} 55 \mathrm{~b} 82 \mathrm{f} 88428 \mathrm{bc} 8 \mathrm{~b} 5 \mathrm{f} 9 \mathrm{~d} 2426 \mathrm{c} \& \mathrm{q}=$ ramacca $\% 20$ castellito\%20mosaici). according to Andronico, it should be searched in district Torricella (Andronico 1983: 13-14), Bonacini proposes district Favarotta - Tenuta Grande (Bonacini 2006: 75-81), Sirena places it in Cozzo Saitano or district Raso (Sirena 2013: $97)$, and recently Bonanno suggested the settlement of Casalgismondo ( $1^{\text {th }}-4^{\text {th }}$ century AD) (Bonanno 2014: 97-98).

Archaeological excavations in Castellitto, carried out since 1978 by the Soprintendenza Archeologica di Siracusa, under the direction of E. Procelli and through seven excavation essays (excavation campaigns 1981-82, 1984-85) brought to light some rooms of the complex, three of them with mosaics and a structure with a curvilinear trend and double floor level referable to a thermal baths (Albanese - Procelli 1988-1989: 7-22).

The excavation campaigns, performed from October 1995 to February 1996 by the Soprintendenza di Catania, allowed the identification of structures related to a Roman rustic villa traditionally organized around a central peristyle, with adjoining thermal structures paved in mortar (Patanè - Buscemi Felici 1997-1998: 200-201). The villa was sacked by vandalism in December 2017 and in MayJuly of the current year (2019) excavations were started by the Soprintendenza Archeologica di Catania, under the direction of Maria Teresa Magro, and the restoration of the mosaics by Arkeo Restauri of Agrigento, financed by the Sicilian Region.

The villa was built in the Republican Age $\left(3^{\text {th }} 2^{\text {th }}\right.$ century BC) on previous structures probably related to a farm of Hellenistic age and the occupation continued until Late Antiquity ${ }^{1}$. To the north of the villa, were found burials, probably relevant to it (Sapuppo 2013: 98).

The complex consists of a series of rectangular rooms with modules of about 17 square meters, arranged around a central courtyard and a small balneum (of which emerged a calidarium, a tepidarium and the prefurnium, see Patanè Buscemi Felici 1997-1998: 200-201). In the light of current scientific knowledge, only the four rooms facing the northern portico have more richly decorated mosaics realized in tessellates, though with geometric decorative patterns (Fig. 2).This situation suggests that the commissioner requested mosaics only in the representative area of the building.

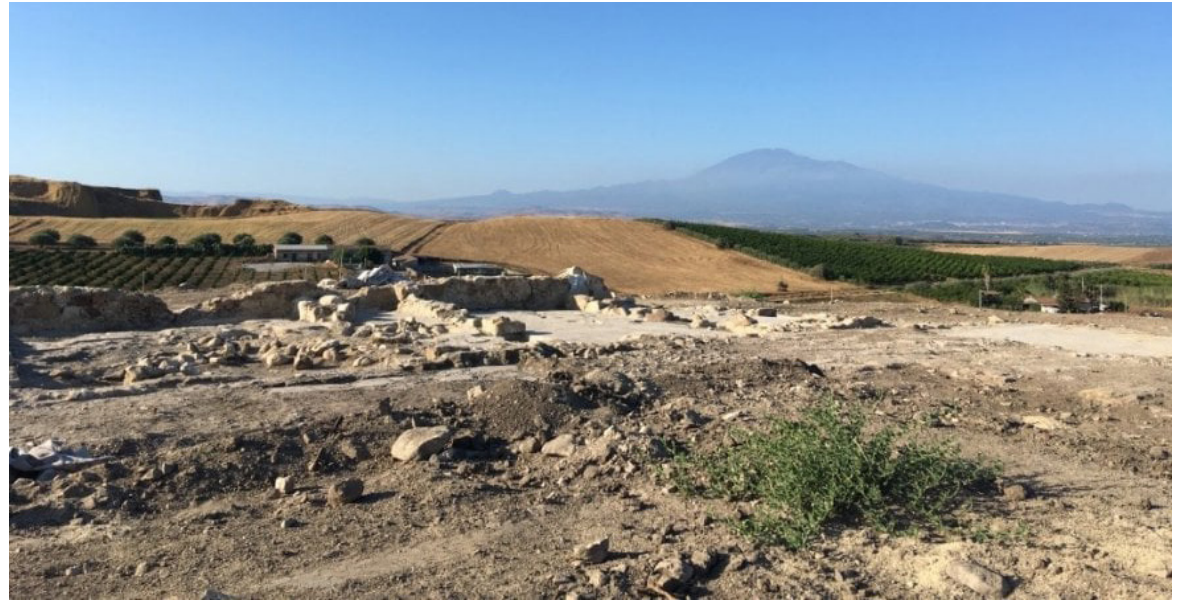

1 Traces of several phases of occupation have been found: the first testimony is constituted by a Hellenistic farm; follows the villa of Republican Age used until the $4^{\text {th }}$ century AD, but materials attest that the area was frequented until the $6^{\text {th }}$ century AD. The material is placed between the full Hellenistic Age and the Late Antiquity: it is reported sigillata italica dated between the middle of the $1^{\text {th }}$ century $\mathrm{BC}$ and the half of the $1^{\text {th }}$ century AD, sigillata africana dating from the $2^{\text {th }}$ century AD. See Albanese - Procelli 1988-1989: 20-21. 
The mosaic floor, visible in situ, covers five rooms $(1,2,3,4,5)^{2}$, incompletely the portico, other fragments of the same floor from unknown origin are kept in the Museo Civico Archeologico of Ramacca. The mosaics are made by a narrow color range of white (for the ground), blue and red (ceramic material-terracotta?) tesserae $^{3}$. The mosaic tesserae used have different sizes, the average oscillates around the $1.5 \mathrm{~cm}$ each side.

Starting from the western end of the northern pavilion, the first room (Room 1 - "essay F", see Albanese - Procelli 1988-1989: 12) presents rectangular plan, the function is unknown. We can see only a fragmentary part of the east side of the mosaic floor, which allows us to hypothesize a possible reconstruction. The mosaic on a white ground presented a composition of swastika-meander with double returns, forming rectangles opposed in pairs (to create double T) with a lozenges included (Fig. 3).

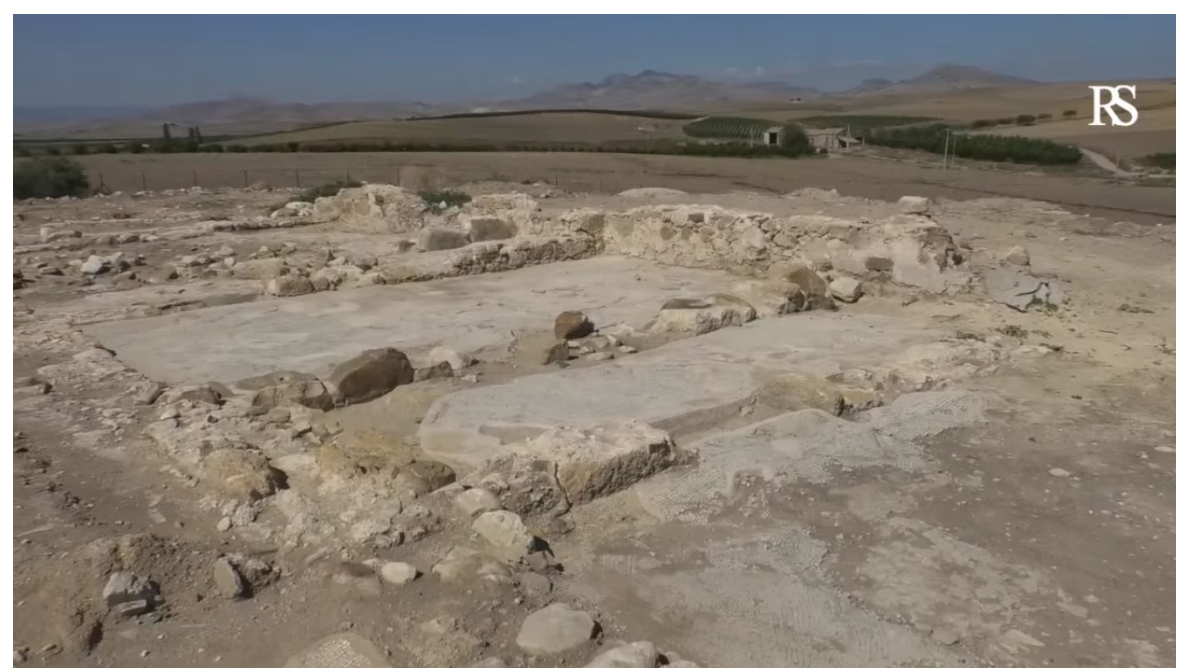

The latter, alternately vertical and horizontal, are outlined by double filet of blue tesserae, containing a crosslet with red chevrons. The mosaic is framed by a double filet of blue tesserae. The compositive scheme is a variant of the $189 \mathrm{c}, \mathrm{d}$ motif (see Décor I: pl. 189c, d with relative bibliography) with lozenges without peltas, therefore our mosaic is less elaborate than the known examples.

This variation of swastika-meander pattern appears from the $2^{\text {th }}$ century BC in the Roman houses ${ }^{4}$, is rather widespread in contexts of $4^{\text {th }}-6^{\text {th }}$ century AD, see a panel of the central nave of the basilica of S. Reparata in Florence $\left(4^{\text {th }}\right.$ - $6^{\text {th }}$ century) with composition described in Décor I: pl. 189d (Bueno 2011: tav. XXXIV, 5); a panel of the eastern ambulatory of the basilica of S. Leucio of Canosa di Puglia (late $5^{\text {th }}-$ early $6^{\text {th }}$ century) with composition in Décor I: pl.189e, in which, in the place of lozenges there are three squares on the diagonal (Moreno Cassano 1976: 341 fig. 20).

2 The rooms have been numbered starting from the west side of the northern portico (Rooms 1-4), therefore the first room that faces to the north end of the east portico, will be $\mathrm{n}$. 5 and so on. The counting of rooms does not take into account the division of the rooms visible today: the mosaic composition of the flooring of Rooms 2 and 3 is cut by dividing walls, forming two spaces for each room, which originally constituted a single environment.

3 The material used, with most probability, is local. The analysis of the materials of the mosaics has not been carried out, immediate archaeometric and petrographic investigations will be performed, which in another context will allow more details in this regard.

4 See numerous sites registered in http://tess.beniculturali.unipd.it/web/ricerca/risultatiricerca/?ricercalibera $=$ meandri $\% 20 \mathrm{di} \% 20$ svastiche $\% 20 \mathrm{a} \% 20$ doppio $\% 20$ giro $\% 20 \mathrm{e} \% 20$ doppie $\% 20 \mathrm{~T}$.
Figure 3

Detail of mosaic fragment in the east side of the Room 1 (photo D. Di Caro). 
The Room 2, also with a rectangular plan, is divided into two rooms in later period, one of which is larger and one more narrow. The fragmentary state makes difficult to read the mosaic, which has, within a double filet of blue tesserae, a composition of circles, squares on the diagonal and rectangles.

The first ones consist of white simple guilloche opened to form eyelets, outlined by red tesserae on a blue ground, and tondo with a floret on a white ground. From what has been received, it can be assumed that around the circles there were eight resulting triangles in differently coloured segments, with effect of eight-pointed stars. The squares containing white Solomon knot outlined in red on a blue ground and the rectangles with an inscribed tassel on a blue ground are bounded by simple white guilloche (Fig. 4).

Figure 4 Mosaic pavement of the narrow sector of the Room 2 (photo D. Di Caro).

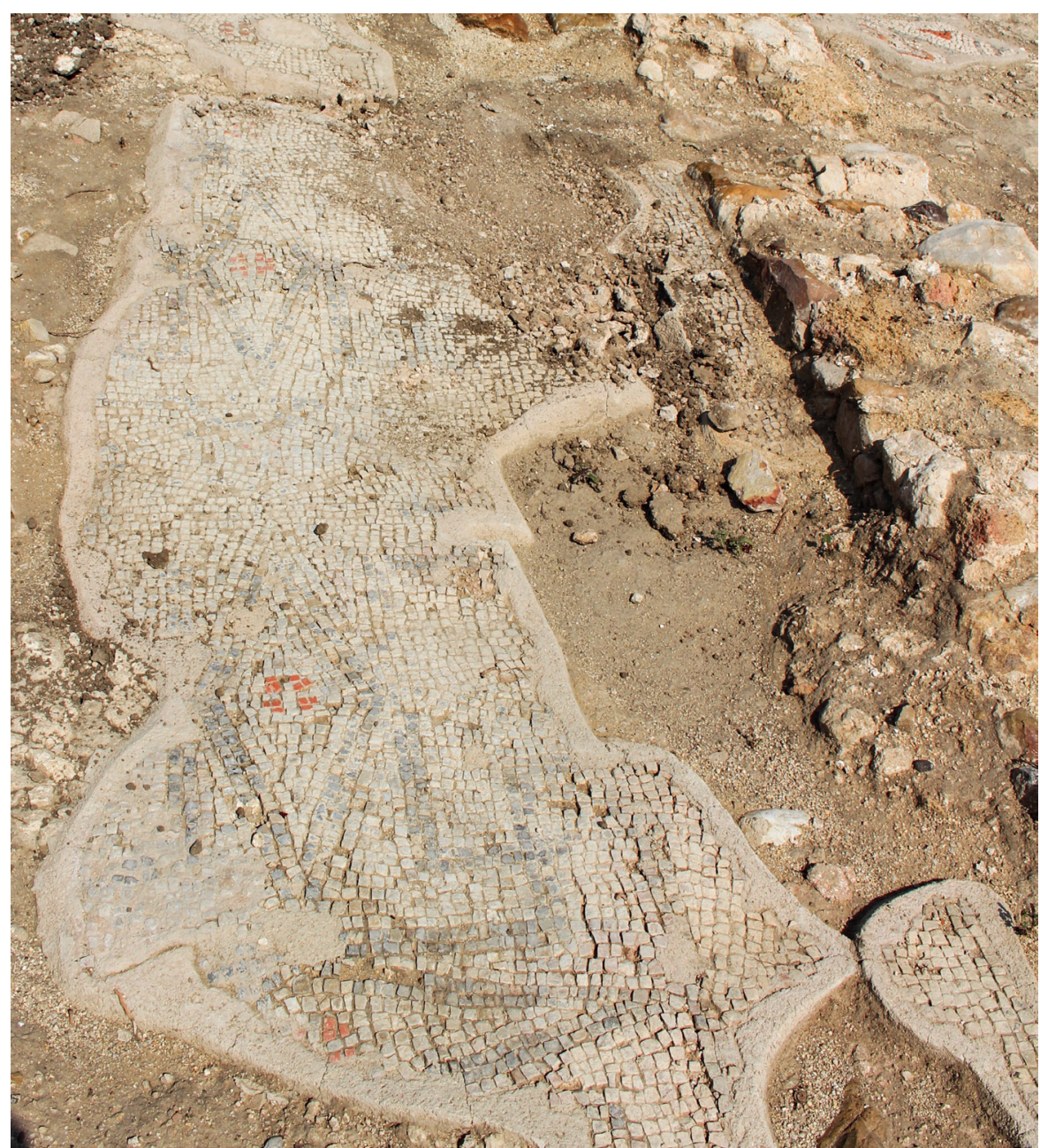

The next Room 3 has the same characteristics as the previous one, which was later divided into two rooms, also here a narrower one and a larger one. The mosaic of the room, brought to light in the essay " $A$ " during the excavations of the 80's (Albanese - Procelli 1988-1989: 12), covers the entire floor surface (Fig. 5 ). It has a frame consisting of double filet of blue-greyish tesserae. The central field, framed by a further double filet, has an orthogonal composition of squares with peltas ending with volutes in each vertex, and not contiguous circles on a white ground (for the graphic typology see Décor I: pl. 226d).

The squares on the diagonal, outlined by quadruple filet of which the central one is red and the remaining ones are blue, containing a serrated floret; the four 


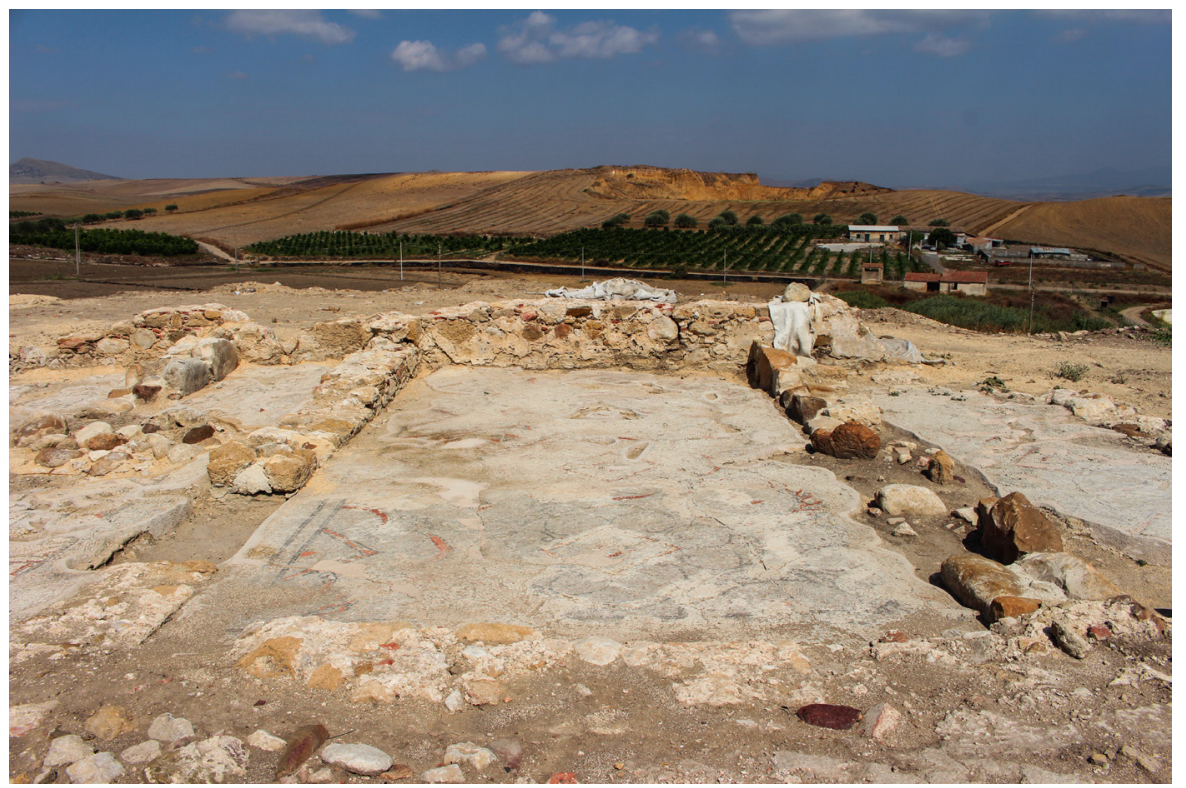

peltas of each square are alternately with red and blue arches, so that the couples of faced peltas appear to contrasting colors.

The circular patterns are delimited by a simple trichrome guilloche that follows the perimeter, inside there is the same floret present in the squares. The squares with peltas and circles pattern (Décor I: pl. 226d) finds close analogies with the fifth-north and fifth-south panels of the nave of the basilica of Monastero of Aquileia, whose mosaic is dated between the end of the $4^{\text {th }}$ and the beginning of the $5^{\text {th }}$ century AD (Bertacchi 1965: 79-134, see 87 fig. 8).

The 4 rectangular Room is located in the northeastern corner of the complex, accessed from Room 3, this reveals the possible function of private room. Half panel of the mosaic that adorned the entrance threshold is preserved: within a box delineated by a filet of blue tesserae, there is half of a square in the center, on the diagonal, with lateral volutes. It contains a motif of red tesserae not identifiable, finally at the corners of the panel there are red tassels.

Also the mosaic of this room is preserved in a rather incomplete way, the fragment of the south-west corner allows to recognize half square placed in diagonal, tangent to the marginal double filet, outlined by a quadruple filet of red and blue tesserae, with quadrilobes on the sides, inscribed within a circle; on the left there is a concave square containing four-spoke circle.

These elements suggest that may be it could be a composition with concave octagons, with a concave square inscribed forming peltas (see graphic reproduction Décor I: pl. 167b). The decorative scheme occurs in Calabria in a panel of a domus of the Parco del Cavallo in Cassano allo Ionio (CS) of the $2^{\text {th }}$ century AD and in the mosaic of the next century of the vestibule of the Villa di Larderia a Roggiano Gravina (CS), reported by Malacrino, who finds strict similarities "in the mosaic of Room 5 of the thermal complex of the villa of Bagnoli S. Gregorio at Capo d'Orlando, dated to the $3^{\text {th }}$ century AD, and Nora, in Sardinia, in a floor dated to the first half of the same century. In Africa the motif is widely diffused, in particular at Thuburbo Majus, in Room XVI of the domus of the Cratere (Corpus Tunisie II, 1: 64-65 pl. XXVI), in the waiting room of the domus of Nettuno (Corpus Tunisie II, 1:144-145 pl. LIV). and on a mosaic so-called Bains des Etoiles (Corpus Tunisie II, 2: 32-35 num. 372A pl. $\mathrm{XIV}$ ), all dated at the beginning or by the middle of the $3^{\text {th }}$ century. Always in
Figure 5

Mosaic pavement of the largest sector of the Room 3

(photo D. Di Caro). 
Thuburbo Majus the scheme continues to be employed still at the end of the fifthbeginning of the $6^{\text {th }}$ century, as witnessed by the floors of the building southwest of the domus of the Carro di Venere (Corpus Tunisie II, 2: 79-83 num. 408A pl. XXXIV)" (Malacrino 2013: 477, see 488 fig. 12).

Among the later examples, datable between the fifth and sixth centuries, there are the mosaic panel of the right aisle of the early Christian basilica of Santi Felice e Fortunato of Vicenza (Lusuardi Siena 1989: 194 figs. 110-111), the trichrome mosaic panel from the casa Braidotti of Cividale del Friuli (UD) (Stucchi 1951: 40-41); the mosaic of the 3 Room of the byzantine Palazzetto in Via D'Azeglio 47 of Ravenna, dated at the end of the $5^{\text {th }}$ - beginning of the $6^{\text {th }}$ century AD (Baldini Lippolis 2004: 90-91 figs. 117-120).

The structure of the portico is not defined since it is still being excavated, regarding mosaic floor, at the current state of research, few scattered traces have emerged in the northern and eastern corridor suggesting that the floor was entirely covered.

Different bichrome fragments of the same flooring are preserved in the warehouse of the Museo Civico Archeologico of Ramacca, of which one is exposed. It presents bands of blue sinusoid filet that join and intersect creating the effect of a net with different mesh, that is so-called composition of "chessboard pattern of double-axes" (Décor I: pl. 221a), here with the two axes outlined. Analogous to our mosaic is the marginal panel, probably relative to the door sill of the Room Q of the Palazzo di Teodorico of Ravenna, dated between the end of $5^{\text {th }}-6^{\text {th }}$ century AD (Farioli Campanati 1973: 325 fig. 4; Berti 1976: 82 tav. LII n. 61 fig. 21).

The rooms of the eastern pavilion which are being excavated, will be thoroughly investigated within the context that has been traced so far.

On the basis of these first stylistic-typological and iconographic comparisons identified, the mosaics of the Castellitto villa can be attributed to the full $5^{\text {th }}$ century $\mathrm{AD}$, as we have seen in the known examples with floors decorated by the same compositions, chronologically referred to the end of the $4^{\text {th }}$ - beginning of the $6^{\text {th }}$ century AD.

This chronology can be verified and reviewed waiting for archaeological data, which will emerge in the further investigations. The mosaics published in the 80 's are mentioned in the wider context of the villa, for which there are no accurate scientific and specific studies.

The recent news about Sicilian Region, for allocating new resources to continue excavation works, for the protection and use of the Castellitto villa and other archaeological sites, bring the hope of new investment for the island's archaeological heritage as a heritage of cultural identity and strategic resource.

New and more exhaustive investigations will therefore allow to define and increase knowledge on the history of the site, with the possibility and the privilege to provide to the scientific community with further insights and clarifications. 


\section{Bibliography - Kaynaklar}

Albanese - Procelli 1988-1989 R. M. Albanese - E. Procelli, "Ramacca (Catania). Saggi di scavo nelle contrade Castellito e Montagna negli anni 1978, 1981 e 1982", NSc, serie VIII, vol. XLII-XLIII, 7-22.

Baldini Lippolis 2004

Bertacchi 1965

Berti 1976

Bonacini 2006

Bonacini 2010

Bonacini - Turco 2015

Bueno 2011

Corpus Tunisie II

Décor I

Farioli Campanati 1973

Lusuardi Siena 1989

Malacrino 2013

Moreno Cassano 1976

Patanè - Buscemi Felici 1997-1998

Procelli 1976-1977

Salmeri 1984

Sapuppo 2013

Sirena 2013

Spigo 1982-1983

Stucchi 1951
I. Baldini Lippolis, “Gli ambienti”, G. Montevecchi (ed.), Archeologia urbana a Ravenna. La "Domus dei Tappeti di Pietra”. Il complesso archeologico di via D’Azeglio, Ravenna, 84-115.

L. Bertacchi, "La basilica di Monastero di Aquileia”, AquilNos 36, 79-134.

F. Berti, Mosaici antichi in Italia, Aemilia. Regione ottava. Ravenna, 1, Roma.

E. Bonacini, “Capitoniana a Contrada Favarotta/Tenuta Grande?”, Valdinoto - Rivista della Società Calatina di Storia Patria e Cultura, 1, Palermo, 65-83.

E. Bonacini, "Una proposta di identificazione lungo la via a Catina-Agrigentum”, Aitna 4, 79-92.

E. Bonacini - M. Turco, "L'insediamento rurale di Contrada Franchetto a Castel di Iudica $(\mathrm{Ct})$. Un sito rurale tra età repubblicana ed età imperiale", FOLD\&R FastiOnLine documents \& research (339), http://www.fastionline. org/docs/FOLDER-it-2015-339.pdf, 1-36.

M. Bueno, Mosaici e pavimenti della Toscana (II secolo a.C. - V secolo d.C.), Roma.

M. A. Alexander - A. Ben Abed (coll. S. Besrour-Ben Mansour - D. Soren et al.) Corpus Tunisie II, Thuburbo Majus, Tunis, 1980-1994 (4 vol.).

C. Balmelle - M. Blanchard Lemée - J. Christophe - J.-P. Darmon - A.-M. Guimier Sorbets - H. Lavagne - R. Prudhomme - H. Stern, Le Décor Géométrique de la Mosaïque Romaine I, Paris, 1985.

R. Farioli Campanati, "Note su alcuni mosaici pavimentali di Ravenna (Collezione Serena Monghini)”, Corsi di cultura sull'arte ravennate e bizantina [XX], (Ravenna, 11-24 marzo 1973), Ravenna, 309-330.

S. Lusuardi Siena, "Vicenza", A. Castagnetti, G. M. Varanini (ed.), Il Veneto nel medioevo. Dalla "Venetia" alla Marca Veronese. II, Verona, 108-127.

C. G. Malacrino, “Architettura e mosaici della villa romana di loc. Larderia a Roggiano Gravina (CS)”, Atti del XVIII Colloquio dell'Associazione Italiana per lo Studio e la Conservazione del Mosaico, Tivoli, 473-489.

R. Moreno Cassano, "Mosaici paleocristiani di Puglia”, MEFRA 88, 277-328.

A. Patanè - G. Buscemi Felici, "Scavi e ricerche a Catania, Licodia Eubea, Grammichele, Ramacca”, Kokalos XLIII-XLIV, II, 1, 200-201.

E. Procelli, "Ramacca, ricerche topografiche nel territorio”, Kokalos XXII-XXIII, 615-618.

G. Salmeri, "Un magister ovium di Domitia Longina in Sicilia", AnnPisa III, 14, 13-23.

L. Sapuppo, "La villa romana di Castellito", E. Procelli (ed.), Catalogo della mostra. Ramacca, Museo Civico Archeologico (5 Aprile 2013), Caltagirone, 98-99.

G. Sirena, "Il territorio in età romana", E. Procelli (a cura di), Catalogo della mostra. Ramacca, Museo Civico Archeologico (5 Aprile 2013), Caltagirone, 95-97.

U. Spigo, "Note preliminari sugli insediamenti di età imperiale romana nei territori di Lentini, Carlentini, Ramacca, Caltagirone, Grammichele", Kokalos XXVIII-XXIX, 341-344.

A. Stucchi, Forum Iulii (Cividale del Friuli): Regio X, Venetia et Histria, Roma. 